\title{
MULTILINGUALISM AS A SIGNIFICANT ELEMENT TO EUROPEAN INTEGRATION Gergana GEORGIEVA
}

\author{
South-West University "Neofit Rilski”, Blagoevgrad, Bulgaria, \\ georgieva@law.swu.bg
}

\begin{abstract}
Since most European nations have been built on the basis of their own languages, it can be said that the European Union is solely based on its linguistic diversity. A sense of common belonging based on linguistic and cultural diversity is undoubtedly a powerful antidote against the manifestations of fanaticism. It is not easy to define exactly or comprehensively the values that everyone should adopt in order to become a full member of the European family. The article aims to prove that the European idea is based on the inextricably linked requirements: universal moral values and cultural diversity. Multilingualism in particular is a unique and significant element to European integration.
\end{abstract}

\section{Keywords: multilingualism, European Integration, European identity}

\section{Introduction}

The European Union comprises 28 countries and 24 official languages in the European Union making multilingualism a challenge and an asset for Europe. Since most European nations have been built on the basis of their own languages, it can be said that the European Union is solely based on its linguistic diversity. Multilingualism has been a fundamental principle of the European Community, which guarantees the equality of every language and a respect for linguistic and cultural diversity. Such respect was "translated" into action from the beginnings of the community, before being formally defined as a policy in itself: therefore, no legislation can come into force at the European level without it being produced in the 24 official languages. Multilingualism is a challenge for Europe, its citizens and the European institutions that need to adapt to successive enlargements and the requirements new languages impose. The usage of translators and interpreters would be more frequent since it is evident that no one would be able to master all the languages of the EU. Thus the translation is the bridge among nations, the key to a mutual understanding and the element to European integration allowing the EU to be more human.

A sense of common belonging based on linguistic and cultural diversity is undoubtedly a powerful antidote against the manifestations of fanaticism. It is not easy to define exactly or comprehensively the values that everyone should adopt in order to become a full member of the European family.

Thus nowadays, it is impossible to design a European policy without integrating multilingualism as a significant factor, which is essential for the democratic foundations of the EU, for its innovative capacity and to assess its influence and relevance. 


\section{European Union Civil Society Platform on Multilingualism}

The Civil Society Platform on Multilingualism was launched by the European Commission in October 2009. Commissioner Leonard Orban called upon the Platform to consult with Civil Society across the EU in order to submit initial proposals to influence thinking at EU, Member State and local level, and to help designing the financial instruments for the new generation of funding programs (20142020). At the inaugural meeting he highlighted the strong existing links between multilingualism, language skills and the creation of new jobs, which are central to the EU2020 strategy.

The 29 member organisations of the Civil Society Platform on Multilingualism have conducted research across Civil Society that enabled them to put together a set of recommendations, directed principally to the European Commission, the Member States and regional administrations. Member organisations are from the education and culture sectors as well as the media. They cover language learning and assessment, multilingual education, literary translations, protection of minority languages, etc. From the perspective of cultural diversity and social inclusion, the learning support to immigrants should be strengthened for integration and social cohesion aims. Public services across Europe should improve their own language skills to be able to offer adequate services.

In order to achieve its targets (raise awareness of the value and opportunities of the EU's linguistic diversity; encourage the removal of barriers to intercultural dialogue and social inclusion; achieve the Barcelona objective to communicate in two foreign languages) the Civil Society Platform aspires to raise the awareness for multilingualism among policy makers, educationalists and adults throughout Europe. In that sense, the Poliglotti4.eu project (early product of the platform - the website poliglotti4.eu that was created with the financial support of the European Commission) has the purpose of setting up an online Language Observatory and highlight good practices that may be transferred to various parts of Europe.

The Platform's goal is to promote multilingualism in Europe as one of the key elements to foster European Integration, promote intercultural dialogue, mutual understanding, cultural diversity, mobility and economic growth in Europe.

The Platform gathers a wealth of expertise in different fields and can provide the Commission with valuable input for its language policies. It is also a forum where the member organisations can exchange best practices and create networks.

\section{Language Policy}

The European Union ability for legislative acts and other initiatives on language policy is based legally in the provisions in the Treaties of the European Union. In the EU, language policy is the responsibility of member states and the European Union does not have a common "language policy." Based on the principle of "subsidiarity," European Union institutions play a supporting role in this area, promoting cooperation between the member states as well as the European dimension in the member states language policies, particularly through the teaching and dissemination of the languages of the member states (Article 149.2). The rules governing the languages of the institutions of the Community shall, without prejudice to the provisions contained in the Statute of the Court of Justice, be defined by the Council, acting unanimously (Article 290).

Every citizen of the Union may write to any of the EU institutions or bodies in one of these languages and have an answer in the same language (Article 314).

In the Charter of Fundamental Rights, legally binding since its inclusion in the Lisbon Treaty, the EU declares that it respects linguistic diversity (Article 22) and 
prohibits discrimination on grounds of language (Article 21). Respect for linguistic diversity is a fundamental value of the European Union, in the same way as respect for the person, openness towards other cultures, and tolerance and acceptance of other people and their culture.

\section{Significance of multilingualism to European integration}

The European idea is based on the inextricably linked requirements: universal moral values and cultural diversity. Orban's opening speech launching the Platform underlined both cultural and economic benefits and challenges to multilingualism. Krzyzanowski and Wodak found that discourses oscillated between those expressing economic values and those expressing traditional European cultural values like diversity and education, but they did not detect a unidirectional shift over time from one to the other. Elsewhere in EU institutional discourses, Wodak observed a "rebranding" of politics and policies of fostering multilingualism as part of a new rhetoric tied to globalization and economic competitiveness. Others have also observed an important shift from discourse invoking rights, identity and cultural-linguistic preservation to one grounded in economic keywords such as "added value", "human capital", reflecting a transition from discourses of pride to those of profit as part and parcel of late capitalist political economies. A critical component of "doing Europe" is "communicating Europe", a field in which the EU is devoting great effort in order to strengthen its legitimacy as well as create and promote a shared sense of identity among citizens. Although some still see multilingualism as a major stumbling block to creating common meanings and values associated with Europeanness, the New Framework Strategy for Multilingualism stressed "respect for linguistic diversity" as "a core value" of the EU, while Multilingualism an Asset for Europe and a Shared Commitment underlined "harmonious co- existence of many languages in Europe" as "a powerful symbol of the European Union's aspiration to be united in diversity, one of the cornerstones of the European project." Indeed, the EU's motto is "unity in diversity". As discourses communicating Europe, such texts do more than announce and create new political and legal structures, institutions, symbols and policies. They also do strategic identity work as they construct a continually evolving narrative articulating multiple meanings of Europe.

Orban's designation of official, regional, minority, and migrant languages within the referential area of "all European languages" signals a move towards a more inclusive language policy grounded in the context of a rights-based approach at the same time as it extends the semantic scope of Europeanness.

\section{Conclusion}

Opponents and proponents of multilingualism agree that absence of a transnational European public sphere is a major source of democratic deficit. De Swaan, for instance, contends that Europeans do not understand each other well enough even to disagree because multilingualism is a barrier to understanding and thus impoverishes political debate. Even political theorists like Kymlicka, who recognize the necessity for a normative theory of language rights grounded in social justice, argue that "linguistic diversity is one of the most important obstacles to building a stronger sense of European citizenship". Lack of a common language, however, does not in itself prevent emergence of a public discursive space or democratic deliberation. If democratic politics is indeed "politics in the vemacular", a truly participatory dialogue should be carried out in as many languages as possible so that further work on the Platform can meet its stated objectives of "putting in place an ongoing process aiming to give a voice to all those committed to promoting multilingualism in Europe" and "bringing multilingualism closer to the citizen". Thus, 


\section{References}

[1] Consolidated version of the Treaty establishing the European Community, Official Journal C 321E of 29 December 2006. Retrieved 1 February 2007.

[2] De Swaan, A. (2001). Words of the world. The global language system. London: Polity.

[3] EU Civil Society Platform on Multilingualism. Available at http://www.poliglotti4.eu/php/about/index.php?doc id=11\&lg=en

[4] EU Civil Society Platform for Multilingualism. Available at http://www.efil.afs.org/advocacy/platforms/eu-civil-society-platform-for-multilingualism/

[5] Gal, S. (2012). Sociolinguistic regimes and management of 'diversity'. In A. Duchene \& M. Heller (Eds.), Language in late capitalism. Pride and profit (pp. 22-43). London: Routledge.

[6] Gal, K., Hicks, D., \& Eplenyi, K. (2011). Traditional minorities, national communities and languages. The issues raised in the European Parliament's Intergroup, 2009

[7] Krzyzanowski, M. (2010). The discursive construction of European identities. A multilevel approach to discourse and identity in the transforming European Union. Frankfurt: Peter Lang.

[8] Krzyzanowski, M., \& Wodak, R. (2010). Hegemonic multilingualism in/of the EU institutions: An inside-outside perspective on the European language policies and practices. In C. Hulmbauer, E. Vetter, \&H. Bohringer (Eds.), Mehrsprachigkeit aus der Perspektive zweier EU-Projekte: DYLAN Meets LINEE (pp. 115-133). Frankfurt: Peter Lang.

[9] Krzyzanowski, M., \& Wodak, R. (2011). Political strategies and language policies: The European Union Lisbon strategy and its implication for the EU's language and multilingualism policy. Language Policy, 10, 115-136.

[10] Kymlicka, W. (2001). Politics in the vernacular: Nationalism, multiculturalism and citizenship. Oxford: Oxford University Press.

[11] Kymlicka, W., \& Patten, A. (2003). Language rights and political theory. Annual Review of Applied Linguistics, 23, 3-21.

[12] Moore, R. (2011). Standardisation, diversity and enlightenment in the contemporary crisis of EU language policy. Working papers in language \& literacies, 74

[13] Multilingualism is a key element in European Integration. Text: Goethe Institut Brussels. Available at http://www.eaea.org/en/home/news/multilingualism-is-a-key-element-ineuropean-integration.html

[14] Romaine, S. Politics and policies of promoting multilingualism in the European Union, Springer Science + Business Media Dordrecht 2013.

[15] The Civil Society Platform on Multilingualism. Available at http://ec.europa.eu/languages/information/language-related-tools/civil-society-platformmultilingualism_en.htm

[16] The European Union and Multilingualism by Catherine Montfort, Translated by Tomas Spragg. Available at http://www.thenewfederalist.eu/The-European-Union-andMultilingualism

[17] Wodak, R. (2007). "Doing Europe”: The discursive construction of European identities. In R. C. M. Mole (Ed.), Discursive constructions of identity in European politics (pp. 70 95). Basingstoke: Palgrave.

[18] Wodak, R. (2008). "Communicating Europe": Analyzing, interpreting, and understanding multilingualism and the discursive construction of transnational identities. Studies in Greek Linguistics. In Proceedings of the annual meeting of the Department of 
Linguistics, School of Philology, Aristotle University of Thessaloniki, 21-22 April 2007 (Language and society series 28). (pp. 57-88).Thessaloniki: University of Thessaloniki Press. 